\title{
ソーシャル・キャピタルとシステム・サポート
}

鹿毛利枝子*

はじめに

本稿は, 日本に拈けるシステム・サポートの規定要因を探る。システム ・サポートは様々に定義されてきたが，本稿では，民主主義的制度に対す る信頼感として定義する。田中愛治による一連の研究が示すように, 現職 政権への支持はシステム・サポートの一部ではあるが，同じではない（田 中 1995, 1996, 2002など)。実際, 現職政権への支持は時期によって大きく 変動してきた一方で, システム・サポートに関する意識構造は, 1976年か ら2001年まで，ほとんど变わっていないという（田中 2002）。

先進諸国に拈いて民主主義体制が定着し，システム・サポートへの関心 は「時代遅れ」だとする見解もある（Torcal and Montéro 2006）。しかし西 ヨーロッパ諸国では反民主主義的な極右政党の台頭も目立ち，システム・ サポートの分析は，未だにその意義を失っていないものと思われる。実際， 1990年代以降, 日本に拈いても景気の低迷, 失業率の上昇, 雇用の不安定 化など, システム・サポートを摇るがしかねない要因が重なってきた。本 稿では，2000年代以降の日本におけるシステム・サポートの規定要因につ いて，とりわけソーシャル・キャピタルが及ぼす影響を検討することで， 今後の展望に繋げたい。

ソーシャル・キャピタルとシステム・サポートの関係については, ソー シャル・キャピタル研究の比較的早い時期から見解が分かれてきた。従来 の研究では, ソーシャル・キャピタルとシステム・サポートを媒介する二 つのメカニズムが提起されている。第一が初期のソーシャル・キャピタル

* 東京大学総合文化研究科准教授 
研究によって主張されたものであり，この観点からは，自発的結社への参 加が一般的信頼をもたらし，ひいては政治制度への信頼も高めるとされる (e.g. Inglehart 1999)。その後，この議論は，「架橋型」「結束型」ソーシャ ル・キャピタルを区別し，とりわけ前者の方が一般的信頼を涵養し，政治 や政治制度への信頼を促進する，という議論へと発展する（Putnam 2000）。 もっともこれらの主張に対しては, 当初から否定的な見解も少なくなかっ た（e.g. Newton and Norris 2000）。第二は近年発達している社会心理学的 な観点からの議論であり, この視点からは, とりわけ「架橋型」のソーシ ヤル・キャピタルが寛容性を䤙成し，ひいてはシステム・サポートを促進 する，とされる (e.g. Mutz 2006)。

このように，ソーシャル・キャピタルとシステム・サポートの間の関係 を強調する論者は, 内容はやや異なりながらも,「架橋型」ソーシャル・キ ヤピタルの重要性を指摘してきた。本稿は，いわゆる「架橋型」ソーシャ ル・キャピタルを従来の研究とはやや異なる形で定式化することで，この ソーシャル・キャピタルとシステム・サポートの間の関係をめぐる論争に 貢献することを試みる。本稿の分析は，いわゆる「架橋型」ソーシャル． キャピタルよりもむしろ「結束型」ソーシャル・キャピタルの方がシステ ム・サポートを促進する可能性を示す。本稿の分析はまた，政権のパフォ ーマンスをめぐる指標やいわゆる「ホーム・チーム」仮説もシステム・サ ポートに一定の影響をおよぼすことを示す。その上で，ソーシャル・キャ ピタルとシステム・サポートの間の媒介变数とされる一般的信頼や寛容性 が，ソーシャル・キャピタルよりもむしろ年齢や性別，イデオロギーとい った要因とより強く結びっいていることを示す。加えて本稿は，システム ・サポートが投票率とは強い関係がみられないものの，イデオロギーとは 一定の関係がみられることを示し，その意味で「民意」を形成する重要な 要因である可能性を指摘する。

本稿の構成は以下の通りである。まず次節では，システム・サポートの 規定要因をめぐる理論状況を整理する。その上で，第 3 節ではソーシャル ・キャピタルとシステム・サポートの間の関係を計量的に検証する。また 従来, ソーシャル・キャピタルとシステム・サポートの間を結ぶ媒介変数 としては「一般的信頼」と「寛容性」という二つの経路が提起されてきた ので，第 4 節では「一般的信頼」「寛容性」とシステム・サポートの間の関 
係を，第 5 節ではソーシャル・キャピタルと寛容性，ソーシャル・キャピ タルと一般的信頼の間の関係を，それぞれ分析する。さらに第 6 節ではシ ステム・サポートが政治参加と政治的イデオロギーに及ぼす影響を分析す る。第 7 節は結びと今後の展望を述べる。

理論的視角

システム・サポートの水準は，どのような要因に規定されるのか。従来 の研究では, システム・サポートの規定要因として大きく四つの要因が挙 げられてきた。

第一は制度的要因である。この議論によると，いわゆる「多数決型」民 主主義においては，「コンセンサス型」民主主義に比べて，システム・开ポ ートが低下しやすいという（Norris 1999b）。「コンセンサス型」民主主義 の下では，自分の支持する政党が政権に参加していなくても自分の政策選 好が一定程度反映される余地があるのに対して，「多数決型」民主主義の下 では少数者の意見は排除されるからである。このロジックに沿えば，日本 においては，小選挙区比例代表制の導入に伴い「多数決性」が強まったこ とにより，システム・サポートが若干低下した可能性はある。もっとも， 多数決性の最も高い制度を採るイギリスやアメリカなどではむしろ他の諸 国と比較してもシステム・サポートの水準は高いので（ibid），制度配置の みがシステム・サポートを規定する決定的な要因であるとはいえないよう である。

第二は政治体制や政権のパフォーマンスである。体制や政権が高いパフ オーマンスを維持することができればシステム・サポートの上昇に繋がり， 逆にパフォーマンスが悪ければシステム・サポートの低迷に繋がるという 主張である。パフォーマンスの指標としては経済パフォーマンス（McAllister 1999; Tanaka 2002) やその国において民主主義体制が持続してきた年 数（McAllister 1999），政治腐敗の多崇（della Porta 2000）などが挙げられ る。日本についても Tanaka (2001) が地域開発や政治腐敗, 治安や環境とい った政権のパフォーマンスがシステム・サポートの重要な規定要因である ことを示している。また世代によってシステム・サポート水準が異なると 指摘する田中 (2002) や Ikeda and Kohno (2008)の議論や，内閣支持率の 影響を指摘する田中（2002）の議論などもシステム・サポートに対するパ 
フォーマンスの影響を重視する主張のバリエーションとして位置づけるこ とができる。

第三は党派性である。この議論によれば，システム・サポートは自分の 支持政党が政権に就いているときには比較的高くなり，就いていないとき には低くなるとされる (Holmberg 1999; Norris 1999b; Anderson and LoTempio 2002; Banducci and Karp 2003)。いわゆる「ホーム・チーム仮説」であ る (Holmberg 1999: 117)。この仮説は, 先にみたパフォーマンス本位の説 明とは理論的に区別される。つまり，自分の支持政党が政権に就いていれ ば，そのパフォーマンスとは関倸なくシステム・サポートが強まり，逆に 支持政党が政権に就いていなければ, パフォーマンスとは無関係にシステ ム・サポートは下がる可能性がある(むらんこれらの議論もパフォーマン スが高ければそれもまたシステム・サポートを強化する効果をもちうるこ とを否定するものではない)。

第四はソーシャル・キャピ夕ルである。既にみたように，ソーシャル． キャピタルがシステム・サポートに繋がるメカニズムとしては，大きく二 つ論じられてきた。一つは自発的結社への参加が一般的信頼を醸成し, ひ いては政治的や政治システムに対する信賴に慗がるという議論である (Putnam 1993; 2000)。いわゆる「架橋型」ソーシャル・キャピタルが一般 的信頼を醇成し，政治システムへの信頼を促進するという主張もこのヴァ リエーションである (Putnam 2000)。

「結束型」「架橋型」ソーシャル・キャピタルを最初に定式化したのはパ ットナムである (ibid)。パットナムによれば,「結束型」ソーシャル・キ ヤピタルは「内向きであり，排他的なアイデンティティや集団の同質性を 補強するもの」である（ibid: 22）。それは「特殊互酬性を補強し，同質的 な集団の動員に適している」ものであり, 具体例としては教会の中の読書 会や，カントリー・クラブなどが挙げられる (ibid)。他方「架橋型」ソー シャル・キャピタルは「外向きであり, 多様な社会的亀裂を架橋して人々 を包摂する」(ibid）。それは，「外部の資産へのアクセスを容易にし，また 情報の伝播を可能にする」ものであり，典型的には公民権運動などが挙げ られる(ibid)。パットナムの主張では, 自発的結社の中でも特に「架橋的」 な結社に参加することは，市民の間の一般的信頼の涵養を促し，ひいては 民主主義に対する支持にも慗がるとされるわけである。 
もっとも，ソーシャル・キャピタルが一般的信頼を介してシステム・サ ポートに繋がるという主張に対しては，比較的早い時期から懷疑的な見解 も提起されてきた。たとえば世界価值観調查を詳細に分析した Newton and Norris (2000)によれば, 一般的信頼は教育や所得, 政治制度に対する信 頼は制度のパフォーマンスと，それぞれ別個の要因に規定されており，一 般的信頼と民主主義的制度に対する信頼との間に直接的な因果関係は確認 できないという。日本についても, Tanaka (2002)の分析が一般的信頼とシ ステム・サポートの間の関係を否定している。

先に見たように，近年では社会心理学の分野から，ソーシャル・キャピ タルとシステム・サポートを慗ぐ別の経路が主張されている。このアプロ 一千は，個々人が多様な見解に接する機会を提供する場としての自発的結 社に対しては懷疑的であり，むしろ職場やインフォーマルなネットワーク など，自発的結社以外の場を重視する（e.g. Mutz 2006）。ムッツによる詳 細な分析が示すように，PTA や業界団体などごく一部の団体を除き，大部 分の自発的結社は同質性が高く，「架橋型」ソーシャル・キャピタルの場を 提供する場として把握するのは現実的でないからである（ibid）。たた，民 主主義体制における架橋的なネットワークの重要性を重視する点では，社 会心理学的なアプローチも, 初期のソーシャル・キャピタル研究も同じで ある。

もっとも, 架橋的ネットワークがシステム・サポートを促進する経路と しては，初期のソーシャル・キャピタル研究が一般的信頼を重視したのに 対して, 社会心理学的アプローチでは他者に対する寛容性を強調する (Mutz 2002b, 2006)。一般的信頼と寛容性は似た概念ではあるが，必ずし も同じではない。たとえば，信頼する相手に対しては寛容でありうるもの と考えられるが，寛容である相手に対して必ずしも信頼をしているとは限 らない。そして社会心理学的アプローチによれば，寛容性こそが，自分の 支持政党以外の政党が政権政党となった場合もその政策を正統なものとし て承認する基盤となるものとされる。多様なネットワークが寛容を生むと いう議論は, Ikeda and Kobayashi (2009) や Ikeda and Richey (2009)の分析に よって日本の文脈においても確認されている。

しかし, これら社会心理学的な研究の究極的な関心が「民主主義体制の 正統性」にあるにもかかわらず，実際に「架橋型」ソーシャル・キャピタ 
ルがシステム・サポートに繋がるか否かについては, 十分に検証されてこ なかった。本稿の狙いの一つは，この間隙を埋めることである。

しかも，日本の文脈でネットワークの多様性が実際に寛容をもたらすか 否かについても，さらに検証の余地がある。上記の Ikeda and Richey (2009) が依拠する「21世紀初頭の投票行動の全国的・時系列的調査研究 (JES III)」 (以下, JES III調查) は回答者に対して「日本の首相や政治家や選挙のこと が話題になる人で, 20 歳以上の方」を最大 4 人まで挙げるよう求め, さら にその相手方それぞれについて，より詳細な設問を設けて情報を得ている。 中でも Ikeda and Richey (2009) が対話ネットワークの多様性の指標として 用いるのは，対話の相手方が次の選挙においてどの政党に投票すると思う か，それが本人の予定する投票先の政党と異なるか否かという指標である。 これはアメリカにおける研究でもしばしば用いられる指標でもある（e.g. Huckfeldt and Sprague 1987; Huckfeldt, Ikeda, and Pappi 2005)。

しかし日本では，投票予定の政党が異なっていても，基本的な考方方や 行動様式にはそれほど違いがないことも珍しくなく，逆に基本的な考え方 や行動様式が大きく異なっていても似たような投票行動をとることも少な くない。たとえばJES III調査（第三波）では，次の選挙において自民党に 投票するとしている回答者のうち，一人目の対話相手が自分と「考え方や 行動のしかた」が似ており，かつ自民党に投票すると考えている者は $47.2 \%$ に過ざない。二人目の対話相手となると $33.0 \%$ までがる。むろん， 回答者の側からの対話相手の投票意図に関する認識は, 必ずしも正確であ るとは限らない（Huckfeldt and Sprague 1987）。しかし回答者のシステム・ サポートに影響を及ぼしうるのは回答者と対話相手の考え方の間に客観的 に相違があるか否かではなく，回答者の側が対話相手と似たような考え方 をもっていると認識しているか否かという，主観的な面であるとすれば (Mutz 2006), 少なくとも, 回答者と相手方の次の選挙における投票意図の 違いをめぐる認識だけでなく，考え方や行動様式の違いについての認識が システム・サポートに影響を及ぼしているか，検討を加える意義は十分に あるものと思われる。

またIkeda and Kobayashi (2009) がネットワークの多様性の指標として用 いるのは, 同じJES III調査の中のいわゆるポジション・ジェネレーターで あり, 弁護士, 医師, 政治家, コンピューター・プログラマーなど $23 に わ$ 
たる職業のそれぞれについて，知り合いがいるか否かを尋ねるものである。 この指標はネットワークの範囲を政治的会話の相手に限っていない点で Ikeda and Richey (2009)の用いるものよりも広く, 本稿もこの指標の有用性 を否定するわけではない。たた，職業が違えば考え方や行動様式も異なる 可能性は高くなるとは考えられるものの，必ず異なるというわけでもない。 ここでもやはり，回答者がネットワーク内の相手方の考え方が自分と違う と認識しているか否かを指標にさらに検証を重ねる余地は十分にあるもの と思われる。

そこで, 以下本稿では, ネットワークの多様性について, 先行研究とは やや異なる形で定式化をした上で，ソーシャル・キャピタルとシステム・ サポートの間の関係を検証する。

検証

\section{(1) データと変数}

前節で述べたように，本節では，「架橋型」ソーシャル・キャピタルを従 来の研究とはやや異なる形で定式化した上で，システム・サポートとの関 係を検証する。分析にはパネルデータである JES IIIデータのうち，第三波 ・第四波（それぞれ2003年 $3 \sim 4$ 月，10～11月実施）を用いる。これらの 調査は，個々人の間のネットワークや接触，団体参加など，ソーシャル． キャピタル関連の多くの情報を含んでおり，本稿の問題関心に好適である からである。

本稿の従属变数であるシステム・サポートについては，これまで様々な 定式化がなされてきた。紙幅の関係から，その整理は他稿に譲るが（田中 1995; Norris 1999a; Torcal and Montéro 2006 など), 本稿では, 主として政治 のインプット側（政党・選挙・国会）の制度に対する信頼として定式化す る。これらは田中（2002）に捛いても，システム・サポートの第一主成分 (「民主主義制度に対する信頼」) として検出されているものである 1 。先に 述べたように，これらは現職政権への支持とは概念上，区別される。また 大部分の回答者にとっては,「政党」「選挙」「国会」は自国のものを想定す るものと思われるので，抽象的な概念としての「政党」「選挙」「国会」一 般に対する支持とも区別される。 
具体的には, JES III（第四波）調査の次の設問を用いる。「次に，政治に ついていくつかの意見があります。これらについて，あなたはどうお感じ になりますか。賛成でしょうか，反対でしょうか。まず，『(1)政党があるか らこそ, 有権者の声が反映するようになる』についてはいかがですか」と いう問いに対して，回答者は「賛成」「どちらかといえば賛成」「どちらか といえば反対」「反対」の四つから選ぶように求められている。さらに，(2) 「選挙があるからこそ，有権者の声が反映するようになる」，(3)「国会があ るからこそ, 有権者の声が反映するようになる」という二つの主張につい ても，同様に四つの選択肢から選ぶように求めている。

本稿では, これら政党・選挙・国会制度に対する態度のそれぞれについ て分析を行うとともに，三つの従属变数について因子分析を行い，共通因 子を抽出して，第四の従属変数とした。三つの变数に共通する，いわば 「システムサポート因子」ともいうべき変数の規定要因を分析するためであ る。

独立変数としては，前節において挙げた(1)制度的要因，(2)パフォーマン ス要因, (3)党派性, (4)ソーシャル・キャピタル要因, のうち, (2)から(4)ま でを検証する。JES III調査の第三波・第四波の時期には選挙制度など大き な統治制度に変更がないので, 残念ながら制度的要因の影響を直接検証す ることはできない。

まずパフォーマンス関連要因については, 内閣支持率の影響を重視する 田中（2002）の議論に沿って，小泉内閣に対する支持の高さをモデルに含 めた。JES III調査（第三波）は回答者に対して，「全体としての小泉内閣の これまでの実績」を「かなり良い」「やや良い」「どちらともいえない」「や や悪い」「かなり悪い」の 5 段階で評価するよう求めているので，この設問 を用いた。

党派性に関するいわゆる「ホーム・チーム」仮説の検証については, 調 查の行われた2003年当時は自民党・公明党・保守新党の連立政権であった ため，「ホーム・チーム」意識をもちうるのはこの三党の支持者であると考 えられる。ただデータ中，保守新党を支持すると表明した回答者は一人も いなかったため，分析に際しては自民党支持者と公明党支持者についての み，それぞれダミー変数を作り，モデルに投入した。なお，自民党支持と 内閣支持の間の相関係数は 0.30 , 公明党支持と内閣支持の間の相関係数は 
0.07であり，前者においてやや高いものの， 分析に深刻な影響は生じないものと思われ る。

ソーシャル・キャピタル要因としては, 三つの变数を用いた。第一に，政治的会話 ネットワークの多様性である。先に述べた ように, JES III調査（第三波）は回答者に 対して，「日本の首相や政治家や選挙のこ
表 1 ものの考え方や行動 の仕方が似ていない相手方 の数

\begin{tabular}{crc}
\hline 相手方の数 & 合計 & 頻度 $(\%)$ \\
\hline 0 & 85 & 4.33 \\
1 & 129 & 6.57 \\
2 & 285 & 14.52 \\
3 & 678 & 34.54 \\
4 & 786 & 40.04 \\
\hline
\end{tabular}

出典 : JES III調查（第四波）。 とが話題になる人で 20 歳以上の方」として挙げられた最大 4 名のそれぞれ について，回答者と「ものの考え方や行動のしかたが似ている」か否かを 聞いている。本稿では，各回答者について，回答者と「ものの考え方や行 動のしかたが似ていない」とされた相手方の人数を合計した。ただし，こ の最大 4 名の対話相手の中には,「配偶者」「配偶者以外の家族」「親戚」も 含まれるため，これら親族の人数を引いた数を「架橋型」ネットワークの 強さとして分析に用いた。対話相手の分布は，表 1 の通りである。

第二に,「架橋的」ネットワークは必ずしも政治的会話の相手を通して測 定する必要はない。既にみたように，JES III（第三波）調査は，回答者に 対して，医師や弁護士，国会議員，ウエイターなど23の職業カテゴリーを 提示して，そのそれぞれについて，知り合いがいるか否かを聞いている。 Ikeda and Kobayashi (2009) もネットワークの多様性の指標として用いるも

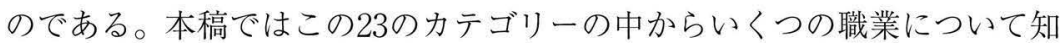
り合いがいるかを合計し，分析に加えた 2 。この質問項目は，特に親しさ の程度は聞いていないので, 知り合いがいるといっても, その大部分はそ れほど親しい間柄ではないものと思われる。つまり政治的対話を行う相手 との関係が「架橋的ネットワーク」の中でも比較的「強い紐帯」であると すれば，この指標は「架橋的ネットワーク」の中でも比較的「弱い紐帯」 の指標として捉えうる。

第三に, 初期のソーシャル・キャピタル研究にならい, 回答者がメンバ 一となっている団体の数を分析に加えた。既にみたように，自発的結社へ の参加がシステム・サポートにもたらす効果については議論が分かれてい るので，分析に加える余地は未だに十分あるものと思われる。JES III調査 は回答者がPTA や生協，学校の同空会など, 13の夕イプの団体のそれぞれ 
表 2 ソーシャル・キャピタル指数の間の相関係数

\begin{tabular}{|c|c|c|c|}
\hline & $\begin{array}{c}\text { 政治的会話 } \\
\text { ネットワークの } \\
\text { 多様性 }\end{array}$ & $\begin{array}{l}\text { 自発的結社 } \\
\text { の会員数 }\end{array}$ & $\begin{array}{l}\text { 知人の } \\
\text { 職業数 }\end{array}$ \\
\hline 政治的会話ネットワークの多様性 & 1.000 & & \\
\hline 参加団体数 & -0.100 & 1.000 & \\
\hline 知人の職業数 & -0.051 & 0.271 & 1.000 \\
\hline
\end{tabular}

出典：JES III調查（第三・第四波）。

についてメンバーになっているか否かを聞いているので，これを合計して モデルに加えた。なお JES III調査は130団体それぞれについて，「積極的 に参加している」か「メンバーになっている程度」かも聞いているので, メンバーとなっている会員数に代えて，「積極的に参加している団体の数」 をモデルに投入して分析したところ，結果に大きな差は見られなかったの で，本稿では回答者がメンバーとなっている団体の数についての結果のみ を示す。大部分の自発的結社は同質性が高く，「架橋的」ソーシャル・キャ ピタルの場は提供していないというムッッの議論が正しければ，この指標 はいわば「結束型」ソーシャル・キャピタルの指標と呼べるかもしれない (Mutz 2006)。しかも, 自発的結社のメンバーとの間の関係は比較的「弱い 紐帯」として把握できるかもしれない。

なお，これら三つのソーシャル・キャピタルの指標の間の相関係数は表 2 の通りである。自発的結社の会員数と知人の職業数の間の相関係数がや や高めであるものの，分析上，深刻な問題は生じないものと思われる。実 際，三つの指標の間の相関関係がそれほど強くないことは，それぞれソー シャル・キャピタルの別個の側面をとらえていることの証左でもあり，ま たいずれもモデルに含める必要性を示すものといえるかもしれない。

その他統制変数としては, 教育水準, 所得, 性別, 持ち家か賃貸かとい う居住形態もを加えた。

\section{(2) 分析結果}

分析の結果は表 3 の通りである。従属变数が「賛成」「どちらかといえば 賛成」「どちらかといえば反対」「反対」の 4 カテゴリーなので，推定には 順序プロビット分析を用いた。

表 3 の結果は, 政治的対話ネットワークの多様性が, すべての従属变数 
表 3 民主主義的制度に対する信頼の規定要因

\begin{tabular}{|c|c|c|c|c|c|c|c|c|}
\hline & $\begin{array}{c}\text { 政党 } \\
\text { (i) }\end{array}$ & 標準誤差 & $\begin{array}{l}\text { 選挙 } \\
\text { (ii) }\end{array}$ & 標準誤差 & $\begin{array}{l}\text { 国会 } \\
\text { (iii) }\end{array}$ & 標準䛊差 & $\begin{array}{l}\text { 共通因子 } \\
\text { (i) - (iii) }\end{array}$ & 標準誤差 \\
\hline \multicolumn{9}{|c|}{ ソーシャル・キャピタル関連指標 } \\
\hline 政治的会話ネットワークの多様性 & -0.087 & $0.043 * *$ & -0.118 & $0.043^{* * *}$ & -0.075 & $0.041 *$ & -0.122 & $0.042 * * *$ \\
\hline 参加団体数 & -0.012 & 0.024 & -0.010 & 0.024 & 0.000 & 0.024 & -0.002 & 0.025 \\
\hline 知人の職業数 ～～～～～ & -0.004 & 0.008 & -0.012 & 0.009 & -0.008 & 0.008 & -0.010 & 0.009 \\
\hline \multicolumn{9}{|l|}{ システム・サポート要因 } \\
\hline 内閣支持 & 0.061 & 0.055 & 0.096 & $0.054^{*}$ & 0.101 & $0.055^{*}$ & 0.095 & $0.056^{*}$ \\
\hline 自民党支持（ダミー） & 0.264 & $0.118^{* *}$ & 0.035 & 0.121 & 0.151 & 0.114 & 0.174 & 0.129 \\
\hline 公明党支持（ダミー） & 0.851 & $0.256^{* * *}$ & 0.711 & $0.251 * * *$ & 0.744 & $0.233^{* * *}$ & 0.815 & $0.180 * * *$ \\
\hline 年齢 & 0.014 & $0.005^{* * *}$ & 0.012 & $0.005^{* *}$ & 0.014 & $0.005^{* * *}$ & 0.016 & $0.005^{* * *}$ \\
\hline \multicolumn{9}{|l|}{ その他統制変数 } \\
\hline 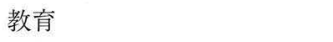 & -0.050 & 0.061 & 0.195 & $0.063 * * *$ & 0.007 & 0.062 & 0.055 & 0.065 \\
\hline 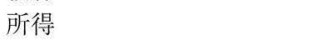 & 0.001 & 0.030 & -0.077 & $0.034^{* * *}$ & -0.012 & 0.033 & -0.037 & 0.034 \\
\hline 持ち家吕貸貸か (0：賃貸, 1 ：持ち家) & -0.085 & 0.162 & 0.090 & 0.179 & -0.072 & 0.168 & -0.088 & 0.172 \\
\hline 性別（0：男性，1：女性） & 0.050 & 0.109 & 0.011 & 0.108 & -0.041 & 0.105 & 0.040 & 0.108 \\
\hline 定数項 & & & & & & & -0.352 & 0.483 \\
\hline $\mathrm{N}$ & \multicolumn{2}{|c|}{487} & \multicolumn{2}{|c|}{502} & \multicolumn{2}{|c|}{485} & \multicolumn{2}{|c|}{472} \\
\hline $\mathrm{R}^{2}$ & \multicolumn{2}{|c|}{0.041} & \multicolumn{2}{|c|}{0.041} & \multicolumn{2}{|c|}{0.032} & \multicolumn{2}{|c|}{0.093} \\
\hline
\end{tabular}

$* * * \mathrm{p} \leqq .01, * * \mathrm{p} \leqq .05, * \mathrm{p} \leqq .1$

政党・選挙・国会についての分析は順序プロビット分析による。

共通因子についての分析は OLS 回帰分析による。

政党・選举・国会については $\mathrm{R}^{2}$ は擬似 $\mathrm{R}^{2}$ ，共通因子については $\mathrm{R}^{2}$ 。標準誤差はいずれもロバスト標準誤差。

に対して有意に負の影響を与えていることを示す。具体的には，他の条件 が同じならば，より多様なネットワーク内にいる回答者の方が，民主主義 的制度に対する信頼は低くなる確率が高い。逆にいえば，より同質的なネ ットワークにいる回答者の方が民主主義的制度に対する信頼は高くなる確 率が高いということでもある。これは，通常のソーシャル・キャピタル論 の想定とは逆の結果であるが，日本に関していえば，ソーシャル・キャピ タルがシステム・サポートには繋がらないとした Tanaka (2002)の分析を部 分的に裏付けるものでもある。

なぜ考え方の似た相手方との対話がシステム・サポートをむしろ強める 効果を生むのか。周囲に同じ見解をもつ者が多ければ，民主主義体制の下 では，自分の意見が政治に反映される可能性も高くなるように思われるの で，その分，民主主義制度の中の，とりわけインプット側の制度に対する 信頼は高まるかもしれない。この点については，さらに検証が必要である。 なおネットワークの均質性・多様性は, 都市部に居住しているか, 地方 に居住しているかという違いに影響を受ける可能性もあるため，念のため， 
居住地の人口規模を統制変数として加えてみたが，結果に大きな違いはみ られなかった。つまりネットワークの多様性の効果は，都市・地方の違い を反映しているわけではなさそうである。

ソーシャル・キャピタル関連のほかの変数に関しては, 加入団体数も, 知人の職業数も，いずれの従属変数に対しても有意な影響は検出されなか った。

パフォーマンス関連の仮説としては，他の条件が同じならば，年齢につ いて強い効果が認められ，比較的若年層についてシステム・サポートが低 い確率が高まり，逆に高齢層について高くなる確率が高まる効果が検出さ れている。これは田中（2002）やIkeda and Kohno (2008)の分析を支持す る結果となっている。また内閣支持については, 政党に対する信頼に対す る影響は認められないものの, 選挙・国会・共通因子に対する信頼に対し て正に有意な影響が認められ，おおむね田中（2002）の議論を支持する結 果となっている。

いわゆる「ホーム・チーム」仮説については，自民党支持の及ぼす影響 は政党制度に対する支持についてのみ認められるが，公明党支持の効果は いずれの従属変数についても 1 \%水準で有意であり, システム・サポート に対するきわめて強い効果が認められる。この公明党支持の及ぼす強いイ ンパクトが, 公明党が連立政権に入るようになって以降の現象なのか, そ れ以前から認められるのかは，今後検証されるべき興味深い問題である。 政党についての分析を除いた三つの分析において，自民党支持がシステム ・サポートに顕著な影響が認められない一方で，公明党支持については強 く認められる理由としては，自民党支持の方が公明党支持よりも流動的で あるからであると推測される。

媒介経路としての信頼と寛容性

\section{（1）理論的視角}

前節の分析は，いわゆる「架橋的」ソーシャル・キャピタルがシステム ・サポートに繋がらないのみならず，むしろ低下させる可能性を示した。 「架橋的」ソーシャル・キャピタルがシステム・サポートに繋がらないとす れば，それはなぜなのか。既にみたように，ソーシャル・キャピタルがシ 
ステム・サポートに繋がる経路として, 従来の研究は二つのメカニズムを 提起してきた。第一が一般的信頼であり，第二が寛容性の醸成である。前 節でみたように，対話ネットワークの多様性がシステム・サポートに繋が らないとすれば，多様な相手方との対話が寛容性の向上に繋がっていない か，一般的信頼にも繋がっていないか，もしくはその双方であるものと考 えられる。本節では，この点を検証する。

本稿でも JES III 第三波デー夕を用いるが，これまでの分析と同様に， 対話ネットワークの多様性について, 相手方の次の選挙における投票意図 ではなく，回答者と相手方の間の「ものの考え方や行動のしかた」の違い の有無についての認識をもとに分析を行う。既に述べたように，日本では， 投票先の政党が違っていても，基本的な考え方や行動様式にはそれほど差 がないことも珍しくなく，逆に基本的な考え方や行動様式が大きく異なっ ていても同様に投票することも考えられるからである。

他者への寛容性や偏見については，いうまでもなく膨大な研究蓄積があ り,ソーシャル・キャピタル以外の要因の重要性も指摘されてきた3。一 つの議論は，教育の効果を強調する。Stephan and Stephan (1984)によると， これは教育が様々な社会的プロセスの複雑性を示し, ステレオタイプが過 度な単純化であることを教えるからであるという。またCoenders and Scheepers (2003) は, 教育が寛容をもたらすのは, それが学生を社会におい て適切とされる規範意識に「社会化」するからであるという。

第二に所得の効果を強調する議論がある。所得の比較的低い者は雇用も 不安定であることが多い。これらの者が教育水準も低いことが多いことも 相まって, 所得の比較的低い者は, 自らの置かれた不遇の要因を, スケー プゴート的に他者に求めることが多いという（e.g. Sniderman et al. 2000; Lubbers et al. 2002)。

第三に, 加齢の効果が指摘される。Henry and Sears (2009) や Cornelis et al. (2009) などは, 高齢者層においてアウトグループへの偏見が他の年齢層 において強いことを検証している。Cornelis et al. (2009)によれば，これは 高齢化に伴い，認知的リソースをより効率的に使うため，ステレオタイプ に依拠する度合いが高まるからであるという。

一般的信頼の規定要因としても，教育や所得，年齢は重要な要因として 指摘されてきたので (e.g. Newton 1999), 前節におけるのと同じ統制変数 
を用いて分析する。

\section{(2) データと変数}

従属変数である「寛容性」の測定については，JES III調査は「家族」「上 司や先輩」「親しい同僚」「親しい友人」の四つのカテゴリーについて，そ れぞれ政治や社会について意見は同じ方がよいか，異なっていてもよいか を 1 （「意見は違っていてもよい」）から 4 （「意見は同じ方がよい」）まで の四段階で尋ねているので，その四つの変数について因子分析を行い，共 通因子を抽出し，従属変数として用いた。分析にはOLS（ロバスト標準誤 差）を用いた。

この指標に問題がないわけではない。この指標が測定するのは比較的近 い関係，いわゆる「イングループ」内における寛容性であり，いわゆる 「アウトグループ」に対する寛容性とは異なる可能性もある。しかしいわゆ る「イングループ」内においてすら意見の相違を許容できない者は，「アウ トグループ」における意見の相違も許容できない可能性は高いのではない かと思われるので，両者は厳密には同じではないものの，寛容性の一つの 指標としては用いうるものと考える。

一般的信頼については，JES III調査は第四波において「ほとんどの人は 信頼できる」という命題に対して，「そう思う」「どちらかといえばそう思 う」「どちらともいえない」「どちらかといえばそう思わない」「そう思わな い」の 5 つの選択肢から一つを選ぶよう，聞いているので，この設問を用 いた。分析には順序プロビット分析を用いた。

ソーシャル・キャピタル関連の指標としては, 前節と同様, ネットワー クの多様性に加えて，参加団体数，知り合いの職業数を加えた。また極端 なイデオロギーをもつ者は寛容性が低い可能性も考えられるので, Ikeda and Richey (2009) や Ikeda and Kobayashi (2009) にならい，イデオロギー変 数を投入する。JES III調査では回答者に対して，0（左）から10（右）まで の軸において自らを位置づけるよう求めているので，このうち0-3まで を「左」，7ー10までを「右」として，それぞれダミー変数としてモデルに 加えた。いわゆる「左」と「右」では寛容性に対するインパクトが異なる 可能性があるからである。その他，統制変数として性別を加えた。 
表 4 寛容性・一般的信頼の規定要因

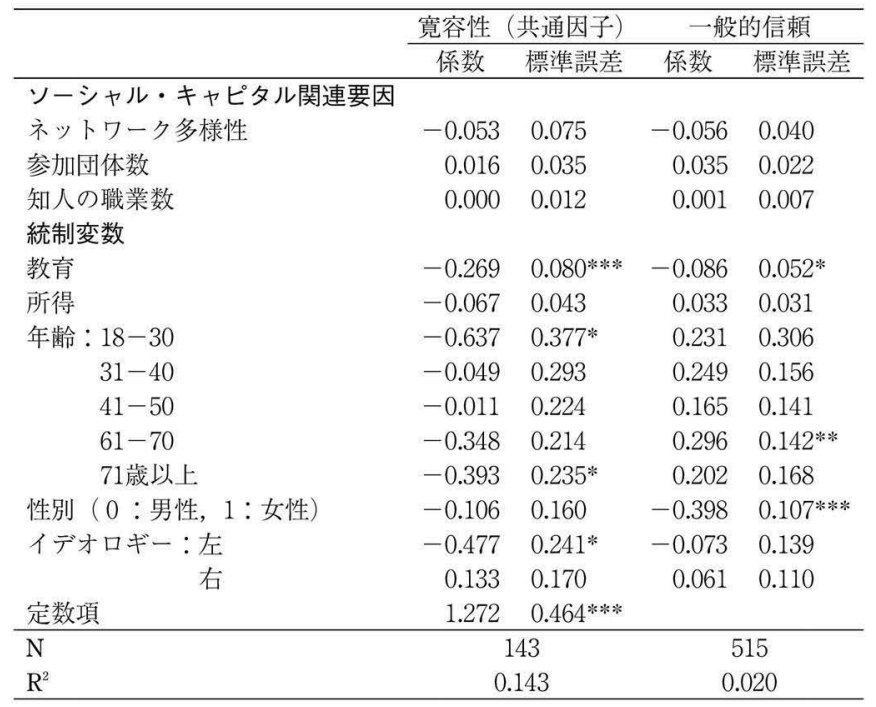

*** $\leqq 0.01, * * \mathrm{p} \leqq 0.05, * \mathrm{p} \leqq 0.1$

寛容性についての分析は OLS 回帰分析，一般的信頼については順序プロビット分析に よる。

誤差はいずれもロバスト標準誤差。 $\mathrm{R}^{2}$ は一般的信頼については擬似 $\mathrm{R}^{2} 4$ 。

\section{(3) 分析結果}

分析の結果は表 4 の通りである。

表 4 の示すように, 分析ではソーシャル・キャピタル関連変数の寛容性 に対するインパクトは検出されなかった。前節において, ソーシャル・キ ヤピタルがシステム・サポートを促進する効果を確認できなった一つの理 由として，日本ではソーシャル・キャピタルが寛容性を促進していない可 能性が示唆される。

表 4 に示す分析結果の中で，今ひとつ注目すべきは教育の効果である。 アメリカやヨーロッパの研究では通常, 教育は偏見を克服する重要な手段 とされており，事実それを裏付ける研究も膨大であるが5, 日本において は教育はむしろ同質性指向を強める影響が認められる。もっとも, Ikeda and Richey (2009) や Ikeda and Kobayashi (2009) では逆に教育は寛容性を高 める効果が報告されているので，この点については今後さらに検証が必要 である。 
その他の変数としては，加齢が寛容性を下げる効果が弱いながら認めら れる。これは, Ikeda and Richey (2009) や Ikeda and Kobayashi (2009)の結果 と同様である。一方で，最も若い18-30歳層についても，比較的寛容性の 低い傾向が認められ，年齢の効果は線形でないことが分かる。イデオロギ 一については，自らを「左寄り」であると認識する回答者（０-10の間で $0-3$ の間に自らを位置づける者) は，イデオロギー線上の中央近辺（4 -6）に自らを位置づける者に比べて，顕著に寛容性が低いという結果が 検出されている。自らを「右寄り」（0-10の間で $7-10)$ であると位置づ ける者は，中央近辺の回答者と顕著な差が検出されていないことから，左 右の寛容性におけるこの非対称性は興味媣い。

一般的信頼についても，ソーシャル・キャピタル関連変数が信頼を高め る効果は確認できなかった。寛容性の場合と同様，一般的信頼の場合も， 教育水準の高い者ほど，信頼がむしろ低くなる傾向が確認された。イデオ ロギーのインパクトは認められないが，寛容性の場合と異なり，ジェンダ 一に強い影響が認められ，他の条件が同じならば，女性の一般的信頼が男 性と比較して顕著に低い傾向が確認される。

本分析において，ネットワークの多様性と寛容性の間に有意な関係が認 められない理由はいくつか考えられる。一つには，従属変数の操作化に原 因がある可能性がある。既にみたように，本稿における「寛容性」の变数 はいわゆる「アウトグループ」というよりは「イングループ」に対する寛 容性の指標である。他方，ネットワークの多様性はイングループの構成員 に対してというよりは，アウトグループのメンバーに対してより強く効く 可能性がある。本節の分析は，アウトグループへの寛容性をめぐるより適 切な指標を用いて，さらに検証されるべきである。

一般的信頼についても, ソーシャル・キャピタル関連変数の効果は認め られなかった。ムッツは多様な見解をもつ他者との対話は, 自分の立場の 「アンビギュイテイ」という形で混乱を招くとするが (Mutz 2002a)，本節 の分析は，それが「アンビギュイティ」を通り越して他者への不信すら招 くということを示すのであろうか。一般的信頼の測定についても様々な議 論が展開されているので，本稿における分析は一つの試みに過ざない。さ らに検証が必要である。 


\section{寛容性・一般的信頼とシステム・サポート}

これまで本稿では,ソーシャル・キャピタルとシステム・サポートの間 の関係，寛容性・一般的信頼とソーシャル・キャピタルの間の関係を検証 してきた。ではソーシャル・キャピタルとシステム・サポートの間の媒介 変数とされる, 寛容性・一般的信頼とシステム・サポートの間の関係はど うか。以下，分析してみた。

従属変数のシステム・サポートは第 3 節と同じ四つの指標である。独立 変数は，前節と同様，寛容性をめぐる設問四つからの共通因子と，一般的 信頼の双方を用いる。その他統制変数としては, 第 3 節の分析に含めた教 育・所得 ·住居形態・性別の四つの变数に加えて, 年齢を投入した。結果 は表 5 に示すとおりである。

表 5 の示すように，寛容性をめぐる共通因子は，いずれの分析において も, システム・サポートに対して有意な影響を及ぼしていない。他方， 一般的信頼は政党に対する信頼を除く三つの分析において，統計的に有意 な効果が認められる。統制変数の中では, 持ち家居住がすべての分析にお いてシステム・サポートに $1 \%$ 水準で有意な影響を及ぼしており，また年 齢も四つのうち三つの分析において 5 \%水準以上で有意である。

\section{表 5 民主主義的制度に対する信頼の規定要因}

\begin{tabular}{|c|c|c|c|c|c|c|c|c|}
\hline & $\begin{array}{l}\text { 政党 } \\
\text { (i) }\end{array}$ & 標準誤差 & $\begin{array}{l}\text { 選挙 } \\
\text { (ii) }\end{array}$ & 標準誤差 & $\begin{array}{l}\text { 国会 } \\
\text { (iii) }\end{array}$ & 標準誤差 & $\begin{array}{l}\text { 共通因子 } \\
\text { (i) - (iii) }\end{array}$ & 標準誤差 \\
\hline \multicolumn{9}{|l|}{ 寛容性指標 } \\
\hline 寛容性（共通因子） & -0.014 & 0.018 & -0.003 & 0.017 & 0.002 & 0.017 & 0.001 & 0.020 \\
\hline 一般的信頼 & -0.090 & 0.059 & -0.182 & $0.062 * * *$ & -0.229 & $0.062 * * *$ & -0.202 & $0.069 * * *$ \\
\hline \multicolumn{9}{|l|}{ 統制変数 } \\
\hline 年齢 & -0.013 & $0.005^{* * *}$ & -0.008 & 0.005 & -0.014 & $0.005^{* * *}$ & -0.015 & $0.006^{* *}$ \\
\hline 教育 & 0.084 & 0.067 & -0.140 & $0.071^{* * *}$ & -0.039 & 0.073 & -0.057 & 0.078 \\
\hline 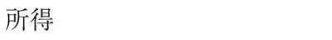 & -0.013 & 0.005 & 0.036 & 0.037 & 0.032 & 0.038 & 0.020 & 0.041 \\
\hline 持ち家加貨貸か (0：賃貸, 1 : 持ち家) & -0.526 & $0.159 * * *$ & -0.465 & $0.159^{* * * *}$ & -0.392 & $0.170^{* * *}$ & -0.657 & $0.218 * * *$ \\
\hline 性別（0：男性，1：女性） & 0.018 & 0.121 & -0.064 & 0.119 & 0.004 & 0.121 & -0.116 & 0.137 \\
\hline 定数項 & & & & & & & 2.329 & $0.608 * * *$ \\
\hline $\mathrm{N}$ & \multicolumn{2}{|c|}{366} & \multicolumn{2}{|c|}{384} & \multicolumn{2}{|c|}{354} & \multicolumn{2}{|c|}{342} \\
\hline $\mathrm{R}^{2}$ & \multicolumn{2}{|c|}{0.0468} & \multicolumn{2}{|c|}{0.0376} & \multicolumn{2}{|c|}{0.0494} & \multicolumn{2}{|c|}{0.1106} \\
\hline
\end{tabular}

*** $\mathrm{p} \leqq .01,{ }^{* * *} \mathrm{p} \leqq .05,{ }^{*} \mathrm{p} \leqq .1$

政党・選挙・国会についての分析は順序プロビット分析，共通因子についての分析は OLS 回帰分析による。

政党・選挙・国会については $\mathrm{R}^{2}$ は擬似 $\mathrm{R}^{2}$, 共通因子については $\mathrm{R}^{2} 。$

標準誤差はいずれもロバスト標準誤差。 
これらの分析からは，以下のように結論づけられる。まず，第 3 節にお いて示されたように，他の条件が同じならば，政治的ネットワークの多様 性は，システム・サポートを低下させることが示された。第 4 節の分析は， この一つの理由が，日本では対話ネットワークの多様性が寛容性にも，一 般的信頼にも繋がっていないためである可能性を示した。その上で，本節 の分析は，日本では寛容性がシステム・サポートを促進する効果を検出し なかったものの，一般的信頼は政党に対する信頼を除けば，システム・サ ポートに対する効果が認められる。

もっとも，一般的信頼がシステム・サポートに対して統計的に有意な影 響を及ぼすといっても，これは必ずしも因果関係を示すとは限らない。た とえば，一般的信頼をもたらす別の要因が，高いシステム・サポートもも たらしている可能性もある。今後さらに検証が必要である。

\section{システム・サポートのインパクト}

民主主義体制に対する支持は，本特集の関心である「民意」にはどのよ うな影響を及ぼすのか。紙幅の関係から，詳細な分析は省くものの，本節 では，(1)投票と，(2)イデオロギーの二つの変数に対するインパクトを検討 する。この二つの変数に注目するのは, 前者が民意が表出する「回路」, 後 者がその民意の「中身」を構成すると考えられるからである。

従属変数は，投票については，JES III調査の第五波（2003年11月実施） のデータを加え，2003年衆議院選挙において投票したか否かを従属変数と して用いた。この值は 0 (棄権) か 1 （投票した）かの二つの值のうち一 つをとるので，分析にはプロビット分析を用いた。イデオロギーについて は，上記のように，JES III調査は回答者のイデオロギー的位置を10段階で 尋ねているので，この設問を用いた。独立変数は，システム・サポートを めぐる四つの変数（政党・選挙・国会に対する信頼，共通因子）である。 これら四つの変数は相互に相関係数が高いため，同時には投入せず，個別 に投入して分析を行った。統制変数としては，年齢・教育・所得 - 性別, 居住形態（持ち家か貨貸か）を加え，また投票については，都市・農村の 違いが影響を及ぼすと考えられることから，モデルに加えた。分析には OLS 回帰分析を用いた。結果は以下表 $6 \cdot 7$ の通りである。 表 6 は, システム・サポートの投票行動へのインパクトの分析結果を示 
表 6 民主主義的制度に対する信頼のインパクト（1）：投票への影響

\begin{tabular}{|c|c|c|c|c|c|c|c|c|}
\hline & 係数 & 標淮䛊差 & 係数 & 標準誤差 & 係数 & 標準䛊差 & 係数 & 標準䛊差 \\
\hline \multicolumn{9}{|l|}{ システム・サポート指標 } \\
\hline 政党に対する信頼（i） & 0.065 & 0.079 & & & & & & \\
\hline 選挙に対する信頼（ii） & & & 0.102 & 0.091 & & & & \\
\hline 国会に対する信頼（iii） & & & & & 0.109 & 0.078 & & \\
\hline 共通因子（i）－（iii） & & & & & & & 0.078 & 0.056 \\
\hline \multicolumn{9}{|l|}{ 統制変数 ～～～～～} \\
\hline 年齢 & 0.001 & 0.005 & 0.002 & 0.005 & 0.003 & 0.005 & 0.002 & 0.005 \\
\hline 教育 & 0.030 & 0.075 & 0.035 & 0.075 & -0.011 & 0.073 & -0.020 & 0.074 \\
\hline 所得 & 0.014 & 0.041 & 0.012 & 0.040 & 0.046 & 0.041 & 0.047 & 0.042 \\
\hline 貢貸か持家加 (0：賃貸，1：持家) & 0.044 & 0.200 & -0.038 & 0.201 & -0.061 & 0.212 & -0.063 & 0.214 \\
\hline 性別（0：男性，1：女性） & -0.173 & 0.129 & -0.179 & 0.128 & -0.158 & 0.133 & -0.158 & 0.135 \\
\hline 人口規模 : 20 万以上 & -0.376 & $0.203 *$ & -0.387 & $0.202 *$ & -0.442 & $0.211 * *$ & -0.432 & $0.214^{* *}$ \\
\hline 10 万以上 & -0.246 & 0.244 & -0.226 & 0.244 & -0.227 & 0.256 & -0.251 & 0.258 \\
\hline 10万未満 & -0.653 & $0.218 * * *$ & -0.609 & $0.216^{* * * *}$ & -0.677 & $0.228 * * * *$ & -0.685 & $0.229 * * * *$ \\
\hline 町村 & -0.360 & 0.231 & -0.318 & 0.228 & -0.362 & 0.240 & -0.384 & 0.241 \\
\hline 定数項 & 1.522 & $0.528 * * *$ & 1.4725 & $0.504^{* * * *}$ & 1.411 & $0.523^{* * * *}$ & 1.661 & $0.500 * *$ \\
\hline $\mathrm{N}$ & \multicolumn{2}{|c|}{696} & \multicolumn{2}{|c|}{720} & \multicolumn{2}{|c|}{688} & \multicolumn{2}{|c|}{665} \\
\hline $\mathrm{R}^{2}$ & \multicolumn{2}{|c|}{0.0271} & \multicolumn{2}{|c|}{0.0258} & \multicolumn{2}{|c|}{0.0325} & \multicolumn{2}{|c|}{0.0321} \\
\hline
\end{tabular}

**** $\mathrm{p} \leqq .01 ， * * \mathrm{p} \leqq .05 ， * \mathrm{p} \leqq .1$ 。分析はプロビット回帰分析による。標準誤差はいずれもロバスト標準誤差。

表 7 民主主義的制度に対する信頼のインパクト（2）：イデオロギーへの影響

\begin{tabular}{|c|c|c|c|c|c|c|c|c|}
\hline & 係数 & 標準誤差 & 係数 & 䅺準誤差 & 係数 & 標準䛊差 & 倸数 & 標準誤差 \\
\hline \multicolumn{9}{|l|}{ システム・サポート指標 } \\
\hline 政党に対する信頼（i） & 0.118 & $0.069 *$ & & & & & & \\
\hline 選挙に対する信頼（ii） & & & 0.122 & $0.072 *$ & & & & \\
\hline 国会に対する信頼（iii） & & & & & 0.195 & $0.068^{* * * *}$ & & \\
\hline 共通因子（i）－（iii） & & & & & & & 0.119 & $0.047^{* *}$ \\
\hline \multicolumn{9}{|l|}{ 統制変数 } \\
\hline 年齢 & 0.033 & $0.004 * * *$ & 0.033 & $0.004 * * *$ & 0.033 & $0.004 * * *$ & 0.033 & $0.004 * * *$ \\
\hline 教育 & -0.103 & 0.064 & -0.125 & $0.063 * *$ & -0.127 & $0.064 * *$ & -0.115 & $0.065 *$ \\
\hline 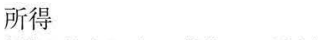 & 0.076 & $0.033^{* *}$ & 0.068 & $0.033^{* * *}$ & 0.073 & $0.034^{* * *}$ & 0.074 & $0.034 * *$ \\
\hline 賃貸か持家か (0：賃貸, 1 : 持家) & 0.042 & 0.146 & 0.054 & 0.144 & -0.048 & 0.146 & -0.057 & 0.149 \\
\hline 性別（０：男性，1：女性） & 0.226 & $0.109 * *$ & 0.218 & $0.108 * *$ & 0.268 & $0.110 * *$ & 0.272 & $0.111 * *$ \\
\hline 定数項 & 2.801 & 0.444 **** & 2.828 & $0.450 * * *$ & 2.647 & $0.448^{* * * *}$ & 3.218 & $0.407^{* * * *}$ \\
\hline $\mathrm{N}$ & \multicolumn{2}{|c|}{1303} & \multicolumn{2}{|c|}{1345} & \multicolumn{2}{|c|}{1281} & \multicolumn{2}{|c|}{1241} \\
\hline $\mathrm{R}^{2}$ & \multicolumn{2}{|c|}{0.0688} & \multicolumn{2}{|c|}{0.0696} & & \multicolumn{2}{|c|}{0.072} \\
\hline
\end{tabular}

**** $\mathrm{p} \leqq .01 ， * * \mathrm{p} \leqq .05 ， * \mathrm{p} \leqq .1 。$ 分析は OLS 回帰分析による。標準誤差はいずれもロバスト標準誤差。

す。国会に対する信頼と，共通因子が10\%有意水準にやや近づくものの， システム・サポートをめぐるいずれの変数も投票に対する有意な効果は検 出されなかった。有意な効果が検証されたのは人口規模をめぐる変数のみ であった。つまり，他の条件が同じならば，システム・サポートの高い有 
権者の「民意」は，低い有権者に比べて，より強く選挙の場において表出 するということはなさそうである。

表 7 は，システム・サポートのイデオロギーに対する効果の分析結果を 示す。いずれのモデルにおいても，システム・サポート変数は10\%水準以 上で有意であった。つまり，他の条件が同じならば，システム・サポート の高い回答者ほど，より「右」に自らを位置づける傾向が強く，システム ・サポートの低い回答者ほど，より「左」の方向に自らを位置づける傾向 が強い。その他，年齢や所得，性別についても統計的に有意な効果がみら れた。

もっとも，システム・サポートとイデオロギーの間に強い連関がみられ るということは，必ずしも両者の間に因果関係があるということではない。 むしろ，因果関係は逆の可能性もある。つまり，イデオロギー的により 「右」に自らを位置づける回答者ほどシステム・サポートが高く, イデオロ ギー的により「左」に自らを位置づける回答者ほどシステム・サポートが 低い可能性もある。この含意としては，システム・サポートが全般的に低 下すれば，より「左」に民意が動く可能性を示唆するが，この点は，時系 列やパネルデータなどを用いてさらに慎重に検証されるべきである。

結語

本稿は，「架橋的」ソーシャル・キャピタルとシステム・サポートの関係 について，前者を従来とはやや異なる形で定式化して分析を行った。その 結果，通説とは逆に，他の条件が同じならば，「結束的」ソーシャル・キャ ピタルがシステム・サポートを促進する効果が認められた。ソーシャル・ キャピタル論においては，いわゆる「架橋的」ネットワークが他者への信 頼，もしくは寛容性を促進し，ひいてはシステム・サポートに繋がるもの と論じられる。しかし本稿の分析では，一般的信頼に対しても，他者への 寛容性の高まりに対しても，架橋的ネットワークの効果は検出されなかっ た。さらには，本稿の分析では寛容性がシステム・サポートを促進する効 果は認められなかったものの，一般的信頼については効果が検出された。 また本特集の関心である「民意」との関係では, システム・サポートは, 投票行動に対する効果は認められなかったものの，イデオロギーを形成す る要因の一つである可能性が示された。 
しかし対話ネットワークの多様性がシステム・サポートを損ない, 逆に 同質性がシステム・サポートを促進するとして，その理由についてはまだ 疑問が残る。既に述べたように，一つの可能性としては，同じ見解をもつ 者が周囲に多ければ，民主主義体制の下では，自分の意見が政治に反映さ れる可能性も高くなるように感じられるので，その分，民主主義制度の中 の，とりわけインプット側の制度に対する信頼は高まるかもしれない。つ まり, 対話ネットワークの多様性は, 政治的有効感覚を介してシステム・ サポートに影響を与えているのかもしれない。もう一つの可能性としては, 多様な対話ネットワークに位置する者は, 政治参加の水準も低下するとい う,ムッツの議論に関わるかもしれない (Mutz 2002a)。その理由としてム ッッは多様な対話ネットワークに位置する者は, 周囲の者に対して自分自 身の見解を明らかにすると社会的な軋轢を生むので，その軋轁を回避する ために参加自体も忌避しょうとする心理が働くため, また様々な政治的見 解に晒されると自分自身の見解に混乱が生じるためであるという，二つの メカニズムを挙げている。そしてこの混乱が政治参加を阻害するのであれ ば，自分たちの参加できない政治制度に対する信頼も低下する可能性があ る。この点は今後さらに詳細に検証する必要がある6。

もっとも，本稿の分析にはまだ限界も多い。既に述べたように，寛容性 をめぐる指標はさらに改善が必要である。また本稿ではネットワーク内の 多様性の指標として「対話相手とのものの考え方や行動の仕方」が似てい るか否かという指標を用いたが, JES III調査では相手方との考え方や行動 の仕方の違いの「有無」しか聞いていないので, 相手とどの程度違うのか, またどのような領域について違うのかといった質や程度の問題については 情報を得ることができない。今後の調査において, 考え方や行動の違いに ついて，その有無だけでなく，方向性や，程度まで捉えることができれば， より詳細な分析が可能になるものと思われる。Mutz (2002b) などは, アフ アーマティヴ・アクションへの態度など, 具体的なイシュー領域を挙げつ つ, 政治的対話の相手との考え方の相違を測っており, 日本の文脈でもこ のような方法は有用であろう。

〔附記〕本稿の分析に際し, 東京大学社会科学研究所附属社会調査・データ アーカイブ研究センターSSJ データアーカイブから〔「21世紀初頭の投票行 
動の全国的・時系列的調査研究 (JES III SSJDA 版)，2001-2005」(JES II 研究会 [池田謙一・小林良彰・平野浩］）］の個票デー夕の提供を受けた。 記して感謝したい。草稿の段階で, 西澤由隆先生, 前田幸男氏より貴重な コメントを頂いた。併せて感謝したい。また本稿の着想のもととなった 2013年度冬学期東京大学総合文化研究科大学院ゼミの参加者のみなさんに も感謝したい。本研究は科学研究費（若手 B·課題番号24730109,「わが国 住宅政策をめぐる比較政治学的研究」) の成果の一部である。

（1） 田中（2002）はシステム・サポートの意識構造として，三つの軸を検 出している。第一が既述の「民主主義制度に対する信頼」, 第二が「政治 アクターの応答性に対する信頼」，第三が「政治コミュニティに対する信 頼」である。

(2) Ikeda and Kobayashi (2009) はこの23のカテゴリーをSSM 調査上の社会 的地位スコアを用いて三つのカテゴリーに分類している。この方法は異な る社会的地位の知り合いがいることが及ほすす効果を推定する上では有用で ある。しかし，異なる職業カテゴリーに知り合いがいることは，それだけ で「架橋的」でもあると考えられる。そこで本稿は知り合いの職業の「数」 を単純に合計して「架橋的」ネットワークの指標とする。

（3）寛容性·偏見をめぐる研究については, Kage (2013) が理論的検討を行 っている。

（4）寛容性をめぐる分析のサンプル数がやや少ない $(\mathrm{N}=143)$ 。これは, 特 に宽容性と参加団体数, 所得をめぐる欠損值によるもので, 三つの設問に すべて答えている回答者はわずかに 163 人に過ぎない。

（5）教育の効果をめぐる理論状況については, Pallas (2000)のレビューに 詳しい。

（6）藤田（2012）のいうように,「結束型」ソーシャル・キャピタルが公 共財の提供を促進するとすれば，これがシステム・サポートを促進する可 能性もある。

\section{参考文献}

Anderson, Christopher J. and Andrew J. LoTempio (2002), "Winning, Losing, and Political Trust in America," British Journal of Political Science, vol. 32, no. 2: 335-351.

Banducci, Susan A. and Jeffrey A. Karp (2003), "How Elections Change the Way Citizens View the Political System: Campaigns, Media Effects, and Electoral Outcomes in Comparative Perspective," British Journal of Political Science, vol. 33, no. 3: 443-467. 


$$
\text { ソーシャル・キャピタルとシステム・サポート }(2014-\mathrm{I})
$$

Coenders, Marcel, and Peer Scheepers (2003), "The Effect of Education on Nationalism and Ethnic Exclusionism: An International Comparison," Political Psychology, vol. 24, no. 2: 313-343.

Cornelis, Ilse, Alain van Hiel, Arne Roets, and Malgorzata, Kossowska (2009), "Age Differences in Conservatism: Evidence on the Mediating Effects of Personality and Cognitive Style," Journal of Personality, vol. 77, no. 1: 51-87.

Dalton, Russell J. (2005), “The Social Transformation of Trust in Government," International Review of Sociology, vol. 15, no. 1: 133-154.

della Porta, Donatella (2000), " Social Capital, Beliefs in Government, and Political Corruption," in Susan J. Pharr and Robert D. Putnam, eds,. Disaffected Democracies: What's Troubling the Trilateral Countries? Princeton: Princeton University Press.

藤田俊介 (2012)「ソーシャル・キャピタルと財政パフォーマンス——都道 府県レベルにおけるパネルデータ分析—」東京大学総合文化研究科修士 論文。

Henry, P. J. and David O. Sears (2009), "The Crystallization of Contemporary Racial Prejudice across the Lifespan,” Political Psychology, vol. 30, no. 4: 569-590. Holmberg, Sören (1999), "Down and Down We Go: Political Trust in Sweden," in Pippa Norris, ed., Critical Citizens: Global Support for Democratic Governance. Oxford: Oxford University Press.

Huckfeldt, Robert, and John Sprague (1987), "Networks in Context: The Social Flow of Political Information," American Political Science Review, vol. 81, no. 4: 1197-1216.

Huckfeldt, Robert, Ken'ichi Ikeda, and Franz Urban Pappi (2005), "Patterns of Disagreement in Democratic Politics: Comparing Germany, Japan, and the United States," American Journal of Political Science, vol. 49, no. 3: 497-514.

Ikeda, Ken'ichi, and Masaru Kohno (2008), “Japanese Attitudes and Values Toward Democracy," in Yun-Han Chu, Larry Diamond, Andrew J. Nathan, and Doh Chull Shin, eds., How East Asians View Democracy. New York: Columbia University Press.

Ikeda, Ken'ichi and Tetsuro Kobayashi (2009), "Making Democracy Work via the Functioning of Heterogeneous Personal Networks," in Ray-May Hsung, Nan Lin, and Ronald L. Breiger, eds., Contexts of Social Capital: Social Networks in Markets, Communities, and Families. New York: Routledge.

Ikeda, Ken'ichi, and Sean Richey (2009), Social Networks and Japanese Democracy: The Beneficial Impact of Interpersonal Communication in East Asia. Abingdon, Oxon: Routledge. 
Inglehart, Ronald (1999), "Trust, Well-Being and Democracy," in Mark E. Warren, ed., Democracy and Trust. Cambridge: Cambridge University Press.

Kage, Rieko (2013), "Japanese Public Attitudes Towards China: A Test of Three Hypotheses," Paper Presented at the Annual Meeting of the Social Science History Association, Chicago, IL.

Lubbers, Marcel, Mégrove Gusberts, and Peer Scheepers (2002), "Extreme Right-Wing Voting in Western Europe," European Journal of Political Research, vol. 41: 345-378.

McAllister, Ian (1999), "The Economic Performance of Governments," in Pippa Norris, ed., Critical Citizens: Global Support for Democratic Governance. Oxford: Oxford University Press.

Miller, Arthur, and Ola Listhaug (1999), "Political Performance and Institutional Trust," in Pippa Norris, ed., Critical Citizens: Global Support for Democratic Governance. Oxford: Oxford University Press.

Mutz, Diana C. (2002a), "The Consequences of Cross-Cutting Networks for Political Participation," American Journal of Political Science, vol. 46, no. 4: 838855.

Mutz, Diana C. (2002b), "Cross-Cutting Social Networks: Testing Democratic Theory in Pratice," American Political Science Review, vol. 96, no. 1: 111-126.

Mutz, Diana C. (2006), Hearing the Other Side: Deliberative versus Participatory Democracy. Cambridge: Cambridge University Press.

Newton, Kenneth (1999), "Social and Political Trust in Established Democracies," in Pippa Norris, ed., Critical Citizens: Global Support for Democratic Governance. Oxford: Oxford University Press.

Newton, Kenneth, and Pippa Norris (2000), "Confidence in Public Institutions: Faith, Culture, or Performance?” in Susan J. Pharr and Robert D. Putnam, eds., Disaffected Democracies: What's Troubling the Trilateral Countries? Princeton: Princeton University Press.

Norris, Pippa (1999a), "Introduction," in Pippa Norris, ed., Critical Citizens: Global Support for Democratic Governance. Oxford: Oxford University Press.

Norris, Pippa (1999b), "Institutional Explanations for Political Support," in Pippa Norris, ed., Critical Citizens: Global Support for Democratic Governance. Oxford: Oxford University Press.

Pallas, Aaron M. (2000), "The Effects of Schooling on Individual Lives," in Maureen T. Halliman, ed., Handbook of the Sociology of Education. New York: Kluwer Academic Publishers.

Putnam, Robert D. (1993), Making Democracy Work: Civic Traditions in Modern 
Italy. Princeton: Princeton University Press.

Putnam, Robert D. (2000), Bowling Alone: The Collapse and Revival of American Community. New York: Simon and Schuster.

Sniderman, Paul M., Pierangelo Peri, Rui J. P. de Figueiredo, Jr., and Thomas Piazza (2000), The Outsider: Prejudice and Politics in Italy. Princeton: Princeton University Press.

Stephan, Walter G., and Cookie White Stephan (1984), "The Role of Ignorance in Intergroup Relations," in Norman Miller and Marilyn B. Brewer, eds., Groups in Contact: The Psychology of Desegregation. Orlando, FL: Academic Press.

田中愛治（1995）「『55年体制』の崩壊とシステム・サポートの継続」『レヴ アイアサン』17号。

田中愛治（2002）「政治的信頼と世代間ギャップ一一政治的システム・サポ 一トの変化—」『経済研究』53巻 3 号。

Tanaka, Aiji (2000), "System Support in Japan (I): Political Culture Explanations vs. System Performance Explanations," Waseda Political Studies, vol. 32: 55109.

Tanaka, Aiji (2001), "System Support in Japan (II): How Democratic Values Have Been Fostered and Changed in Japan's Postwar and Post-Industrial Periods," Waseda Political Studies, vol. 33: 1-20.

Tanaka, Aiji (2002), "Does Social Capital Generate System Support in Japan? An Empirical Analysis of Political System Support," Waseda Political Studies, vol. 34: 51-72.

Torcal, Mariano, and José Ramón Montéro (2006), "Political Disaffection in Comparative Perspective," in Mariano Torcal and José Ramón Montéro, eds., Political Disaffection in Contemporary Democracies: Social Capital, Institutions, and Politics. Abingdon, Oxon: Routledge. 